\title{
tRNA-Derived Small RNAs: Novel Epigenetic Regulators
}

\author{
Joonhyeong Park ${ }^{1}$, Se Hee Ahn ${ }^{2}$, Myung Geun Shin ${ }^{1}$, Hak Kyun Kim ${ }^{1, *} \mathbb{C}$ \\ and Suhwan Chang $2,3, *$ [D \\ 1 Department of Life Science, Chung-Ang University, Seoul 06974, Korea; marcosweet98@gmail.com (J.P.); \\ mmmk8569@gmail.com (M.G.S.) \\ 2 Department of Biomedical Sciences, University of Ulsan College of Medicine, Asan Medical Center, \\ Seoul 05505, Korea; sayahn92@gmail.com \\ 3 Department of Physiology, University of Ulsan College of Medicine, Asan Medical Center, Seoul 05505, Korea \\ * Correspondence: hakyun@cau.ac.kr (H.K.K.); suhwan.chang@amc.seoul.kr (S.C.); \\ Tel.: +82-2-820-5197 (H.K.K.); +82-2-3010-2095 (S.C.)
}

Received: 4 September 2020; Accepted: 24 September 2020; Published: 27 September 2020

Simple Summary: Cells must synthesize new proteins to maintain its life and tRNA (transfer RNA) is an essential component of the translation process. tRNA-derived small RNA (tsRNA) is a relatively uncharacterized small RNA, derived from enzymatic cleavage of the tRNAs. Accumulating evidences suggest that tsRNA is an abundant, highly modified, dynamically regulated small-RNA and interacts with other types of RNAs or proteins. Moreover, it is abnormally expressed in multiple human diseases including systemic lupus, neurological disorder, metabolic disorder and cancer, implying its diverse function in the initiation or progression of such diseases. In this review, we summarize the classification of tsRNA and its role focused on the epigenetic regulation. Further, we discuss the limitation of current knowledge about the tsRNA and its potential applications.

Abstract: An epigenetic change is a heritable genetic alteration that does not involve any nucleotide changes. While the methylation of specific DNA regions such as CpG islands or histone modifications, including acetylation or methylation, have been investigated in detail, the role of small RNAs in epigenetic regulation is largely unknown. Among the many types of small RNAs, tRNA-derived small RNAs (tsRNAs) represent a class of noncoding small RNAs with multiple roles in diverse physiological processes, including neovascularization, sperm maturation, immune modulation, and stress response. Regarding these roles, several pioneering studies have revealed that dysregulated tsRNAs are associated with human diseases, such as systemic lupus, neurological disorder, metabolic disorder, and cancer. Moreover, recent findings suggest that tsRNAs regulate the expression of critical genes linked with these diseases by a variety of mechanisms, including epigenetic regulation. In this review, we will describe different classes of tsRNAs based on their biogenesis and will focus on their role in epigenetic regulation.

Keywords: transfer RNA; tRNA fragment; tRNA-derived small RNA; tsRNA; tRF; tiRNA; epigenetics; cancer

\section{Introduction}

Progress in next-generation sequencing technologies has led to the rapid identification and study of various types of small RNAs [1]. Among them, tRNA-derived small RNAs (tsRNAs) or tRNA-derived fragments (tRFs) are emerging as important RNA regulators [2,3]. A tsRNA is a short noncoding RNA (14 to $40 \mathrm{nt}$ long) generated non-randomly by the action of nucleases on tRNAs $[4,5]$. 
Even though proteins are composed of various permutations and combinations of 20 different amino acids, the number of genes coding for tRNAs that carry these amino acids is over 500 [6,7].

Accordingly, the variety of existing tsRNAs seems to exceed every estimation till date. Consequently, tsRNA characterization and annotation guidelines have been developed [8,9]. So far, 232 annotated tsRNAs have been included in the Cancer Genome Atlas (TCGA) and the NCI-60 cell line screen databases [10], but this number will certainly increase.

tsRNA function is an attractive, rapidly expanding area of study within noncoding RNA biology [11]. As a tRNA is a key component of translation, one of the major functions of tsRNAs is most likely translation; a few seminal reports have supported this idea [12,13]. Val-tRF, a tRF from a halophilic archaeon, has been reported to compete with mRNAs for the ribosome, which results in global attenuation of translation in response to stress [14]. In addition, the regulation of RPS28 by LeuCAG3'tsRNA represents a typical mode of regulation by tsRNAs [15]. However, accumulating evidence indicates that tsRNAs play a key role in several processes other than translation; these include maintenance of mRNA stability [16,17], gene silencing [5,18], reverse transcription [19], and gene regulation [20]. These biochemical functions are expected to affect diverse cellular phenotypes. For example, tsRNAs derived from tRNA(Glu), tRNA(Asp), tRNA(Gly), and tRNA(Tyr) suppress cancer cell growth and metastasis [16]. In contrast, tsRNA-26576 promotes breast cancer cell proliferation while inhibiting apoptosis [21], and tRF-03357 promotes ovarian cancer cell growth and migration [22]. In addition, tRF5-AlaCGC enhances the secretion of IL-8 in response to arsenite, via p65 activation [23].

In addition to these functions, accumulating evidences demonstrates that tsRNA has value as a biomarker $[17,24,25]$. Because the small RNAs are less susceptible to degradation, the detection of tsRNA in various biofluids, such as serum/plasma, urine, and bile is quite feasible [26]. Indeed, a recent report successfully detected tsRNA from 10 kinds of body fluids and showed clear differences in the expression patterns, compared with miRNA [27]. Moreover, some of tsRNA expressions were shown to be correlated with human diseases, including infection [28], prostate/breast cancer [25,29] and myelodysplastic syndromes (MDS) [30]. Despite of this, the detection of tsRNA by conventional small RNA-seq has limitations due to the heavy modification of tsRNA, which inhibits reverse transcription in the RNA-seq procedure [7,31]. With the improvement of accurate detection methods, the tsRNA is anticipated to be used as a diagnostic or prognostic biomarker for various human diseases.

With this accumulating information regarding tsRNAs, there are critical points that should be further investigated to fully understand the mechanisms of action of these versatile small RNAs. First, there are only few known nucleases that cleave tRNAs, including angiogenin [23], RNase P [32,33], RNase Z [4,5], and Dicer [34], which generate a variety of tsRNAs [26]. Bioinformatic analyses suggest that approximately 200 RNA nucleases are capable of cleaving tRNAs (our unpublished data). Hence, a complex network might be involved in regulating tRNA cleavage (and biogenesis), with implications in cellular physiology and human diseases; this network might warrant further investigation. Second, it is believed that many non-RNA molecules interacting with tsRNAs may exist; these need to be identified. Until now, only a few such molecules have been described, including RNA-binding proteins [16,35], FZD3 [36], and Piwil2 [37]. Considering the complexity of tsRNAs and that they may be induced $[23,38]$, there should also be a group of effectors that directly bind tsRNAs. Lastly, the role of tsRNAs in various human diseases needs to be clarified. A recent study profiling tsRNAs in cancer [25,39], suggested the existence of tissue specific signatures. Further studies will reveal the role of these tissue-specific tsRNAs in cancer initiation and progression.

Since the 1980s, abnormalities in DNA methylation patterns have been identified in cancer cells [40]. Epigenetic mechanisms have often been found to be dysregulated in cancer and have become the focus of cancer research [41,42]. A number of enzymes generating or removing epigenetic marks have been identified through post-translational modification (PTM) mapping. Mutations in these enzymes have been commonly found to be related to cancer. Recently, whole genome/exome sequencing on tumor cells has revealed that epigenetic changes could give rise to cancer, suggesting that epigenetic changes might be involved in tumor suppressor gene inhibition or oncogene activation [42,43]. In addition, several 
evidences support the association between cancer and epigenetic changes. First, many known tumor suppressor genes have been found to be silenced by hypermethylation [44]. Second, epigenetic writers and readers are required for tumor development in murine cancer models [45-47]. Third, changes in DNA methylation patterns are essential for cancer cell survival [48]. These findings highlight the critical role of epigenetic regulation in cancer development.

The role of small RNAs in epigenetic modifications has been relatively well demonstrated in the PIWI protein-interacting RNA (piRNA) pathway. piRNAs guide PIWI proteins toward nascent transcripts of a given transposon and generate heterochromatin by either DNA or histone methylation $[49,50]$. Interestingly, a pioneering study has revealed that Twi12, a PIWI protein from Tetrahymena, carries a tRNA fragment [51]. Besides, it has been revealed that tsRNAs behave like piRNAs [37,52]. Hence, it is possible that tsRNAs are involved in epigenetic regulation along with PIWI proteins. In this review, we summarize the current knowledge on the classification and biogenesis of tsRNAs and on the epigenetic mechanisms involving tsRNAs and their potential applications.

\section{Classification and Biogenesis of tRNA-Derived Small RNAs}

Transfer RNAs (tRNAs) are noncoding RNAs (76-93 nt long) essential for mRNA translation. Each tRNA contains an anticodon sequence that recognizes a specific codon triplet sequence on a mRNA and transfers the corresponding amino acid to a growing polypeptide chain [7].

tRNA precursors (pre-tRNAs) are transcribed by RNA polymerase III. They contain $5^{\prime}$ leader and $3^{\prime}$ trailer sequences and undergo splicing, processing, and post-transcriptional modifications (PTMs); a CCA sequence is added at the $3^{\prime}$ termini during the tRNA maturation process [53]. Each mature tRNA contains, on average, 13 modified nucleotides, which affect their stability and functions [54]. tRNAs are folded into L-shaped structures containing three loops (i.e., the D-loop, T-loop, and anticodon loop) (Figure 1).

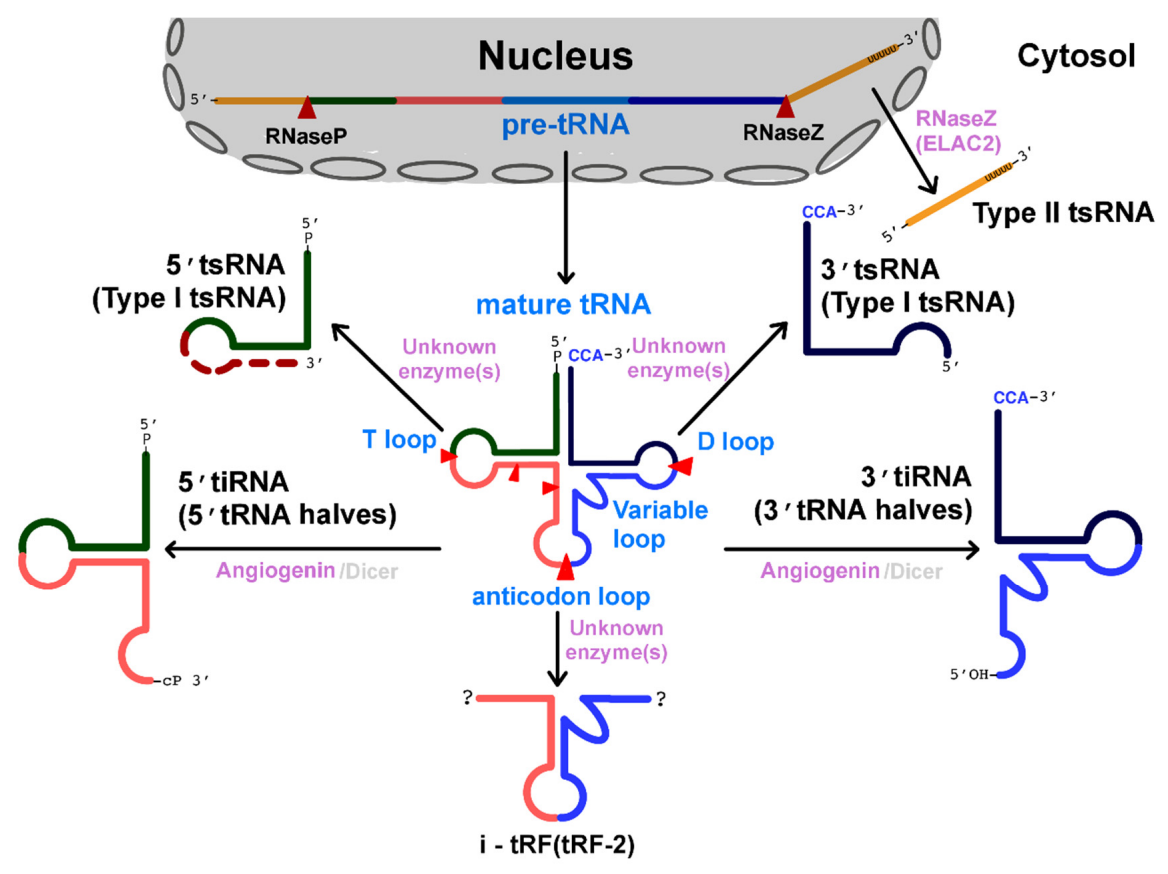

Figure 1. Classification and biogenesis of tRNA-derived small RNAs. More than 6 types of tsRNAs have been classified based on the site at which precursor tRNAs are cleaved. tsRNAs are formed by the processing of their precursors (i.e., mature tRNAs or pre-tRNAs). Cleavage sites are indicated by red arrowheads. Variations in length observed in 5' tsRNAs (Type I tsRNAs) are indicated by a red dotted line. tRNA halves are primarily processed by angiogenin and Dicer proteins (the name of the minor processing enzyme is shown in gray). The major processing enzymes for other tsRNAs generated from mature tRNAs have not been determined. 
In humans, mutations, modifications, or dysregulations of tRNAs are associated with several disorders, including myoclonic epilepsy and ragged-red fiber disease (MERRF), mitochondrial encephalomyopathy, lactic acidosis, strokelike episodes (MELAS), and a variety of cancers (breast cancer, lung cancer, cervical cancer, prostate cancer, pancreatic cancer, and multiple myeloma) [55,56]. Moreover, it is becoming increasingly clear that tsRNAs (tRNA- or pre-tRNA-derived small RNAs) are also strongly associated with human diseases, such as amyotrophic lateral sclerosis (ALS) and several cancers, including lung, colorectal, prostate, breast, and ovarian cancers $[4,16,21,56,57]$.

tsRNAs are also called tRFs (tRNA-derived fragments) or tiRNAs (stress-induced tsRNAs) $[4,58]$. As they are generated by a variety of cleavage events, the classification of tsRNAs is dependent on the site at which tRNAs are cleaved.

\subsection{Type I tsRNAs: Cleavage at the Stem-Loops (D-Loop and T-Loop) of Mature tRNAs}

Type I tsRNAs are generated by cleavage at either the D- or T-loops of mature tRNAs (Figure 1). Type I tsRNAs are classified into $5^{\prime}$ tsRNA (tRF-5 or $5^{\prime}$ tRF) and $3^{\prime}$ tsRNA (tRF-3 or $3^{\prime}$ tRF), which are processed from the $5^{\prime}$ and $3^{\prime}$ ends of mature tRNAs, respectively [5]. The length of the $5^{\prime}$ tsRNAs from different origins, such as HEK293 cells, prostate cancer cells, and Haloferax volcanii, is quite heterogeneous. For instance, $5^{\prime}$ tsRNAs of various lengths (14-16 nt (tRF-5a), 22-24 nt (tRF-5b), and 28-30 nt (tRF-5c) long) have been identified. Their $5^{\prime}$ termini coincide with the $5^{\prime}$ ends of the precursor tRNAs, whereas their $3^{\prime}$ termini are either around the D- or the anticodon loops of the precursor tRNAs. In contrast, most $3^{\prime}$ tsRNAs are 18 or $22 \mathrm{nt}$ long. Their $5^{\prime}$ termini are in the T-loop, and their $3^{\prime}$ termini correspond to the CCA sequence that is post-transcriptionally added to the $3^{\prime}$ ends of a tRNA during maturation $[59,60]$.

The processing enzymes catalyzing the formation of type I tsRNAs have not been clearly determined. The microRNA-processing enzyme Dicer was first identified as the protein responsible for processing the $3^{\prime}$ ends of the Ile tRNA precursor and type I tsRNAs, such as Gln5' tsRNA, Gly3' tsRNA (CU1276), and Lys3' tsRNA (PBSncRNA) [2,61-63]. However, high-throughput sequencing analysis demonstrated that most type I tsRNAs are not processed by any known miRNA-processing enzymes, including Dicer [60,64], suggesting that tsRNA biogenesis might be different from microRNA biogenesis.

\subsection{Type II tsRNAs: Cleavage at the $3^{\prime}$ Trailer Sequence of Pre-tRNAs}

RNase P and RNase Z respectively, process the $5^{\prime}$ leader and $3^{\prime}$ trailer sequences of pre-tRNAs in the nucleus during maturation. Released $3^{\prime}$ trailer sequences become $14-48 \mathrm{nt}$ long tsRNAs, called type II tsRNAs. Their $5^{\prime}$ termini begin after the $3^{\prime}$ ends of the tRNA genomic sequence, whereas their $3^{\prime}$ termini are formed by polyuridine tails, RNA pol III termination signals $[5,65]$.

Although type II tsRNAs are thought to be generated in the nucleus, it has been reported that a type II tsRNA, tRF-1001, is generated in the cytoplasm by ELAC2, a tRNA 3'-endonuclease encoded by a prostate cancer susceptibility gene $[4,66]$. This finding raises the possibility that type II tsRNAs might originate from multiple biogenesis pathways.

\section{3. tRNA Halves: Cleavage at the Anticodon Loop of Mature $t R N A s$}

tsRNAs, 30-40 nt in length, that are generated by cleavage at the anticodon loop of tRNAs are called tRNA halves as they are almost half the length of their precursor tRNAs [67]. As previously mentioned, they are also referred to as tiRNAs because they are induced in response to several stress conditions [58]. tiRNAs are simply classified into two groups (i.e., $5^{\prime}$ tiRNAs and $3^{\prime}$ tiRNAs). The $5^{\prime}$ termini of $5^{\prime}$ tiRNAs correspond to the $5^{\prime}$ ends of the precursor tRNAs, whereas the $3^{\prime}$ termini are within the anticodon loop of the precursor tRNAs. Consequently, the $3^{\prime}$ ends of $3^{\prime}$ tiRNAs are matched to the CCA sequence at the $3^{\prime}$ termini of the precursor tRNAs, and their $5^{\prime}$ ends are a part of the anticodon loop $[58,68]$.

Since the first observation of tiRNAs from Escherichia coli, the biogenesis of tiRNAs has been reported in various species, including Tetrahymena thermophila, some fungi, and several mammalian cells 
and tissues [16,23,67,69-73]. The major enzyme involved in the generation of tiRNAs is angiogenin, a member of the RNase A superfamily [58,73]. Under normal conditions, angiogenin is localized within the nucleus or is present in its inactive form in association with RNH1, an angiogenin inhibitor. However, under stress conditions, angiogenin is released from the nucleus or dissociated from RNH1 and cleaves tRNAs at their anticodon loop to process tiRNAs [74-77]. It has also been reported that angiogenin and Dicer are required for processing tRF5-AlaCGC (tRNA halves) under conditions of arsenite treatment [23].

\subsection{Cleavage at Other Regions of $t R N A$ s or Pre-tRNAs}

Other types of inducible tsRNA, known as i-tRF or tRF-2, include the anticodon-containing internal region of their precursor tRNAs; their length is variable $[16,78,79]$. Finally, there is a group of tsRNAs whose $5^{\prime}$ ends correspond to the $5^{\prime}$ ends of the leader sequences of pre-tRNAs, whereas their $3^{\prime}$ ends correspond to the $5^{\prime}$ exon halves of the anticodon loops [80]. The detailed biogenesis of these two types of tsRNAs has not been described.

Taken together, tsRNAs can be processed or generated by enzymatic cleavage at specific sites; this demonstrates that these RNAs are not simple degradation by-products and suggests that different types of tsRNAs have distinct biogenesis and may have distinct biological roles as well. Importantly, although hundreds of tsRNAs have been identified using current high-throughput sequencing technologies $[9,10,81]$, no consistent naming conventions have been established, which can serve as a major obstacle in tsRNA research.

\section{Epigenetic Role of tsRNAs as PIWI-Interacting RNAs}

Generally, small RNAs (sRNAs) are classified based on transcript origin, processing pathway, or protein partner. Among sRNA categories, piRNAs, mostly 24-32 nt in length, are found [82]. PIWI proteins belong to the Argonaute/PIWI family, and PIWI-piRNA complexes determine the fertility of various animal species, including mouse, zebrafish, Drosophila, and Caenorhabditis elegans, via epigenetic regulation of genes involved in developmental pathways in germ and stem cells [83-86]. Functional studies on the PIWI-piRNA complex suggest that noncoding RNA-associated PIWI proteins may play an important role in epigenetic regulation in germ cells as well as in somatic cells [87]. One of the major studies on tsRNAs focused on the epigenetic role of PIWI-tsRNA complexes, based on the length similarity between tsRNAs and piRNAs as well as their interactions with PIWI proteins.

\subsection{Role of PIWI-tsRNA Complexes in the Regulation of RNA Processing in the Nucleus}

Couvillion et al. demonstrated that type I $3^{\prime}$ tsRNAs associate with PIWI proteins in Tetrahymena [88]. They analyzed Twi (Tetrahymena PIWI)-interacting small RNAs based on high-throughput sequencing and determined that a variety of unpredictable 23-24 nt long sRNAs were associated with a number of Twi family proteins, such as Twi1, Twi2, Twi7, Twi 8, Twi9, Twi10, Twi11, and Twi12. Interestingly, these sRNAs showed differential dependence on the abundance of distinct Twi proteins [88].

After this initial finding, they identified that $3^{\prime}$ tsRNAs (18-22 nt in length) were associated with Twi12. Structurally, such $3^{\prime}$ tsRNAs begin in the T-loop of the tRNA and end at variable positions of the tRNA $3^{\prime}$-CCA tail. Twi12 is located in the nucleus and is essential for cell growth, suggesting that Twi12-interacting tsRNAs might play a role in cell proliferation as well (Figure 2A) [51]. 


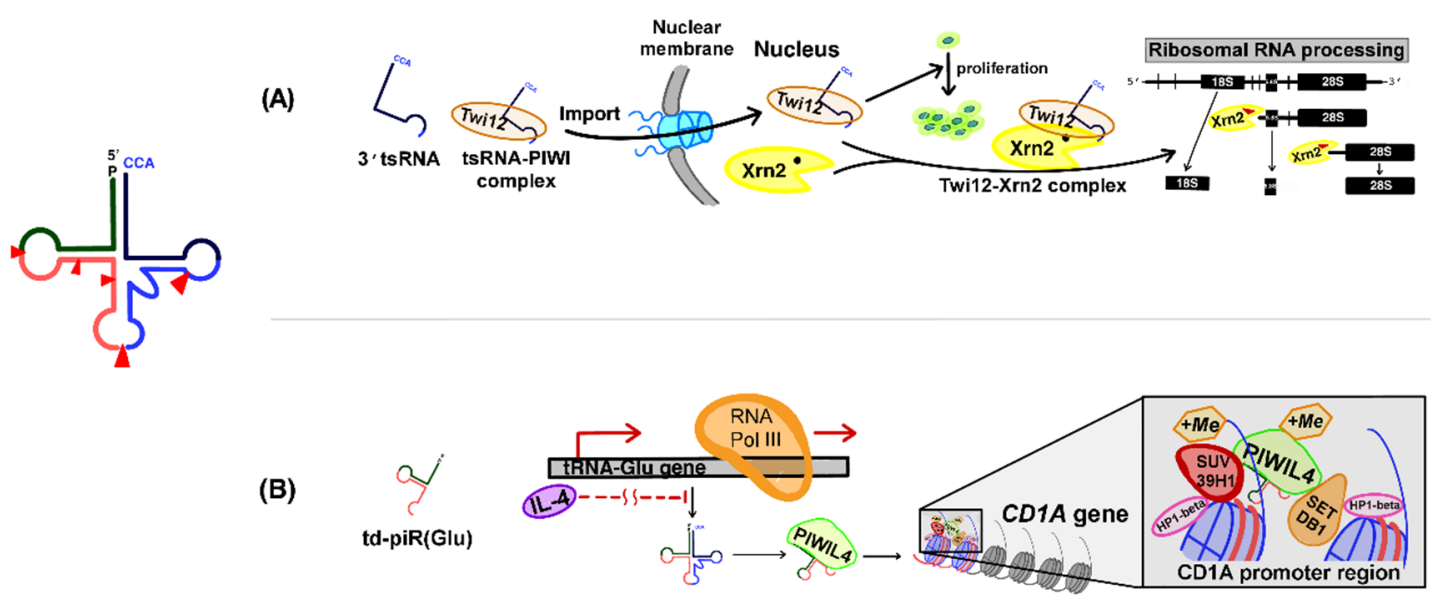

Figure 2. PIWI-dependent epigenetic regulation and function of tRNA-derived small RNAs: (A) Regulation of RNA processing in the nucleus. The Twi12-3' tsRNA complex plays a role in cell proliferation. It also plays a role in the stabilization and nucleolar localization of Xrn2, a $5^{\prime}$ monophosphate-dependent nuclear exonuclease that is required for ribosomal RNA processing in the nucleus. (B) Histone modification in immune cells. IL-4 affects tRNA(Glu) expression; consequently, it inhibits the expression of the tRNA(Glu)-derived piRNA (td-piR(Glu)) precursor. td-piR(Glu) associates with PIWIL4 and recruits H3K9 methyltransferases (SETDB1 and SUV39H1) and heterochromatin protein $1 \beta(\mathrm{HP} 1 \beta)$ to the CD1A promoter region, thereby facilitating $\mathrm{H} 3 \mathrm{~K} 9$ methylation. Hence, the transcription of CD1A is inhibited.

In a follow-up study, Couvillion et al. demonstrated that the Twi12-3' tsRNA complexes localized and stabilized Xrn2 within the nucleus and stimulated its exonuclease activity for ribosomal RNA processing [89]. In addition, $3^{\prime}$ tsRNAs are required for the nuclear import of Twi12. These findings demonstrate that tsRNAs are novel piRNAs and that tsRNA-PIWI complexes play a role in RNA metabolism in the nucleus (Figure 2A) [89].

\subsection{Role of PIWI-tsRNAs in Histone Modification in Immune Cells}

Zhang et al. showed that tsRNAs modulate histone methylation in human monocytes that can differentiate into dendritic cells (DCs) in response to stimulation by several cytokines, including IL-4 [90]. They performed small RNA deep sequencing and found that tRNA halves, such as tRNA(Glu)-derived piRNA [td-piR(Glu)], td-piR(Gly), and td-piR(Pro), were expressed at higher levels in human monocytes than those in differentiated DCs. These td-piRNAs are approximately $29 \mathrm{nt}$ long and contain a $2^{\prime}$-O-methylated $3^{\prime}$-terminus, as is observed in most piRNAs. Their sequence is identical to the $5^{\prime}$ half of the corresponding mature tRNA, suggesting that they are a type of tsRNA. They found that td-piR(Glu) interacted with a protein from the PIWI family, PIWIL4, and recruited H3K9 methyltransferases (SETDB1 and SUV39H1) and heterochromatin protein $1 \beta(H P 1 \beta)$ to the $C D 1 A$ promoter region. As a result, H3K9 methylation was facilitated at this region, leading to the inhibition of $C D 1 A$ transcription. The authors also identified that IL-4 suppressed tRNA(Glu), resulting in td-piR(Glu) expression. These results demonstrate that tsRNAs are IL-4-regulated signal molecules capable of regulating the chromatin states in immune cells [90]; they also suggest that more tsRNAs might be involved in epigenetic regulation in somatic cells (Figure 2B).

\section{3. tsRNA Interactions with PIWI Proteins in Human Cancer Cells}

Interactions between tsRNAs and PIWI proteins have also been observed in chronic lymphocytic leukemia (CLL) [91]. Type II ts-101 and ts-53 were originally identified as microRNAs (miR-4521 and miR-3676, respectively); they bind to Ago1 and Ago2 proteins and regulate gene silencing. Ts-53 inhibits the expression of T-cell leukemia/lymphoma 1 (TCL1) mRNA by binding to its $3^{\prime}$ UTR. In addition, 
TCL1 is critical for the development of aggressive CLL. Thus, ts-53 loss derepresses TCL1 expression, thereby resulting in CLL progression [91]. In addition, Pekarsky et al. found that ts-101 and ts-53 interact with PIWIL2 (human Piwi-like protein), but the function of the tsRNAs-PiwiL2 complex is yet to be determined [52].

\section{PIWI-Independent Epigenetic Roles of tsRNAs}

\subsection{Regulation of Transposons by tsRNAs}

Transposons are genetic elements that can "move" from one location in the genome to another [92]. Genome sequencing has revealed that two classes of transposon elements (TEs) constitute a substantial fraction of most eukaryotic genomes [92,93]. Class I transposons (retrotransposons) can be moved by a "copy and paste" mechanism through the action of a reverse transcriptase enzyme that creates a copy of the TE. This copy is then inserted elsewhere in the genome, leaving behind the original copy. In contrast, class II transposons can move from one place to another by a "cut and paste" mechanism through the action of transposases that cut out a TE from its original location and prepare the new site where it will be inserted [92,94,95].

The transposition activity of TEs contributes to the genetic diversity of all organisms and has been shown to be helpful during adaption to stress conditions [96]. However, TEs can cause genetic mutations and result in the development of several diseases, such as cancers (like colon, breast, ovarian, and liver cancers), neurological disorders (like multiple sclerosis, Rett syndrome, and autism spectrum disorders), and blood diseases [92,94,95,97,98].

One of the main roles of piRNA-Piwi protein complexes in germ cells is to protect the genome from the invading TEs by post-transcriptional silencing and DNA methylation [97,99-101]. However, piRNA levels gradually decrease, while tsRNAs are enriched during sperm maturation and early embryo development in mice [102], suggesting that tsRNAs might replace the role of piRNA in cells or tissues devoid of piRNA.

Recently, Andrea et al. discovered that $3^{\prime}$ tsRNAs (18 and $22 \mathrm{nt}$ in length) containing the 3 '-terminal CCA sequence of mature tRNAs could inhibit long terminal repeat (LTR)-retrotransposons (also known as endogenous retroviruses; ERVs) [103]. It is known that Setdb1 mediates histone H3K9 trimethylation and inhibits most of the LTR-retrotransposons, and that Dnmt1 mediates DNA methylation and inhibits most of the non-LTR-retrotransposons [104,105]. It has been shown that the levels of both 18- and 22-nt-long type I 3' tsRNAs were elevated in Setdb1-/- but not in Dnmt1-/mouse embryonic stem cells (mESCs), suggesting that $3^{\prime}$ tsRNAs might play a role in the regulation of LTR-retrotransposons. Indeed, 18-nt $3^{\prime}$ tsRNAs blocked the reverse transcription of ERVs by competing with mature tRNAs for binding to the PBS (primer binding site) in ERVs. In addition, $22 \mathrm{nt} 3^{\prime}$ tsRNAs induce post-transcriptional silencing of ERV mRNA. Taken together, both $18 \mathrm{nt}$ and $22 \mathrm{nt}$ long $3^{\prime}$ tsRNAs suppress LTR-retrotransposon activity by different mechanisms involving sequence complementarity with the PBS sequence (Figure 3A) [103].

\subsection{Regulation of Chromatin Accessibility by tsRNAs}

It is widely known that chromatin accessibility is one of the critical factors in the regulation of gene expression. Accessibility is determined by the state of the chromatin in the form of either heterochromatin (solid form) or euchromatin (fluid form). Moreover, the flexibility of the chromatin regulates the expression levels of relevant genes without altering the DNA sequences [106]. Besides, small noncoding RNAs are involved in chromatin accessibility in C. elegans and Drosophila [107-109]. Especially, siRNAs and piRNAs have been identified as regulators of heterochromatin formation in eukaryotes [110]. 
(A)

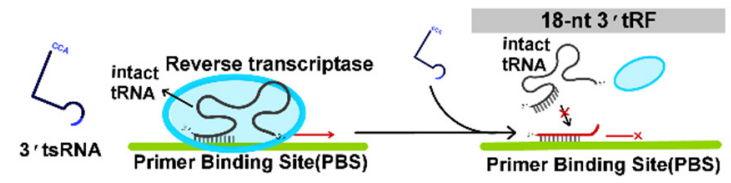

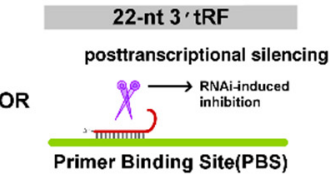

posttranscriptional silencing

Primer Binding Site(PBS)

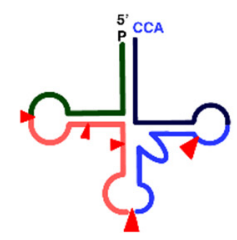

(B)

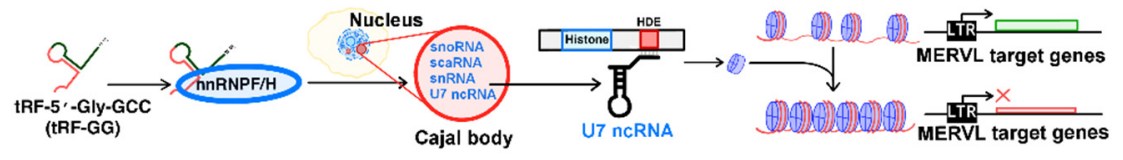

(C)

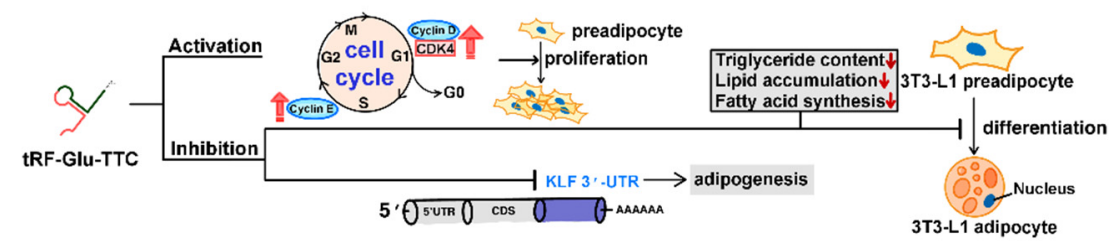

Figure 3. PIWI-independent epigenetic regulation and function of tRNA-derived small RNAs (A) Regulation of transposon activity. Intact mature tRNAs play a role as primers during the reverse transcription of ERVs; $3^{\prime}$ tsRNAs (18-nt long; red line) interrupt this process by competing for the primer binding site (PBS), whereas $22 \mathrm{nt}$ long $3^{\prime}$ tsRNAs induce post-transcriptional silencing of retroviral proteins by targeting their mRNA. (B) Regulation of chromatin accessibility; $5^{\prime}$ tRF-Gly-GCC (tRF-GG) directly binds to heterogeneous nuclear ribonucleoproteins $\mathrm{F}$ and $\mathrm{H}$ (hnRNP F/H), thereby forming a complex. This complex is required for the biogenesis of a normal Cajal body. Further, U7 snRNA is required for histone expression by base pairing with the histone downstream element (HDE). Consequently, elevated histone levels affect the expression of MERVL-associated genes via altering the chromatin status (euchromatin to heterochromatin). (C) Regulation of adipogenesis. Increased levels of $\mathrm{tRF}$ GluTTC induce the expression of several cell cycle regulatory factors, such as Cyclin D1, CDK4, and Cyclin E, thereby promoting preadipocyte proliferation, while inhibiting 3T3-L1 preadipocyte differentiation. $\mathrm{tRF}^{\text {GluTTC}}$-mediated inhibition results in reduced expression of fatty acid synthesis-related genes and a decrease in triglyceride content and lipid accumulation. Finally, increased levels of $\mathrm{tRF}$ GluTTC inhibit result in the inhibition of mRNA translation of Krüppel-like factor (KLF) family members through hybridization to KLF 3' UTR.

Recently, Sharma et al. identified a specific tsRNA (tRNA halves), $5^{\prime}$ tRF-Gly-GCC (tRF-GG), as a suppressor of genes associated with the endogenous retroelement MERVL, which is packaged into and repressed by heterochromatin in embryonic stem (ES) cells and preimplantation embryos [111]. The mechanism underlying this regulation was further determined by Boskovic et al. [35], who discovered that the modulation of tRF-GG levels in human and mouse ES cells affected the production of various RNAs, such as snoRNAs, scaRNAs, and snRNAs, whose stability and function are dependent of Cajal bodies (subnuclear organelles). Among these RNAs, the snRNA U7 is required for processing histone $3^{\prime}$ UTRs via base pairing to the histone downstream element (HDE), thereby regulating histone expression. The modulation of histone expression results in downstream effects on the expression of MERVL-associated genes in murine ES cells and preimplantation embryos. Therefore, tRF-GG affects chromatin accessibility in MERVL elements and throughout heterochromatin [35]. In addition, it was determined that tRF-GG directly bound to heterogeneous nuclear ribonucleoproteins $\mathrm{F}$ and $\mathrm{H}(\mathrm{hnRNP} F / \mathrm{H})$, which are required for normal Cajal body biogenesis, suggesting that hnRNP F/H might play a role in tRF-GG-mediated regulation (Figure 3B) [35]. 
Studies on the role of tsRNA in the regulation of chromatin accessibility are just in their infancy, and more efforts will be needed to understand the detailed mechanism underlying this process.

\subsection{The Role of tsRNAs in the Regulation of Adipogenesis}

Shen et al. suggested that type I $5^{\prime}$ tsRNAs might act as novel epigenetic molecules regulating adipogenesis [112]. To determine the role of tsRNAs in adipose tissues affected by obesity-induced stress, tsRNA sequencing was performed using perirenal fat from high-fat-diet (HFD)- and low-fat-diet (LFD)-fed mice groups. A total of 296 tsRNAs from the HFD and LFD mice groups displayed differential expression. Among them, 170 tsRNAs were upregulated in the HFD group, whereas 126 tsRNAs were upregulated in LFD group. Such a change in the tsRNA profile suggested that tsRNAs might regulate perirenal fat deposition in vivo [112].

tRF GluTTC showed aiding in suppression of 3T3-L1 preadipocyte. Moreover, tRFGluTTC downregulates the mRNA expression of Krüppel-like factor (KLF) family members (KLF9, KLF11, KLF12, and KLF13) [112], which are transcriptional regulators play an important roles in adipogenesis during processes such as cell development and differentiation [113-115]. The members of the KLF family play an important role in expression among the 296 differentially expressed tsRNAs between the HFD and LFD groups [112]. tRFGluTTC promotes preadipocyte proliferation via increasing the expression of cell cycle regulatory factors, such as Cyclin D1, CDK4 (cyclin-dependent kinase 4), and Cyclin E [112], which are essential for the maintenance of the G1/S phases in mammalian cells [116,117]. tRFGluTTC also reduces fatty acid synthesis-related gene expression, triglyceride content, and lipid accumulation, lent roles in adipogenesis (Figure 3C) [112]. These findings suggest that tsRNAs could serve as novel therapeutic targets during obesity treatment.

\subsection{Role of tsRNAs in the Regulation of Intergenerational Inheritance}

Intergenerational inheritance refers to the transmission of an epigenetic trait from one generation to the next [118]. It may include nongenetic materials, such as proteins and metabolites, and RNA. The role of tsRNAs in intergenerational inheritance was first identified in a study on HFD-fed mice, in which it was shown that sperm tsRNAs (tRNA halves) contributed to the transmittance of acquired metabolic disorder to the next generation [119]. Likewise, a protein restriction study in mice demonstrated that the upregulation of a $5^{\prime}$ fragment of glycine tRNA resulted in downregulation of the MERVL retroelement both in sperm and egg cells [111]. A more recent report further showed that low-protein diets affected tsRNA biogenesis, thereby supporting the role of tsRNAs in the transmission of metabolic phenotypes [120]. Further, a switch in the RNA payload from piRNAs to tsRNAs in the sperm maturation process indicates that they may be involved in epigenetic inheritance [121]. Related to this, a study using knockout mice showed that the loss of the nucleic acid modification enzyme DNMT2 prevented the intergenerational inheritance of a HFD-induced metabolic disorder [122]. Moreover, it was shown that the absence of DNMT2 resulted in abolished sperm tsRNA modification and expression changes, thereby indicating the critical role of tsRNAs in epigenetic mechanisms.

\subsection{Translation Regulation by tsRNAs in Cancer}

The role of tsRNAs in translation regulation was first reported for tRNA-derived stress-induced fragments (tiRNAs) that inhibit translation initiation by displacing the eIF4F complex from mRNAs [123]. Likewise, pseudouridylation of type I $5^{\prime}$ tsRNAs by PUS7 was reported to control the function of the translation initiation complex in hematopoietic stem cells [31]. Another study revealed an alternative pathway in which the $5^{\prime}$ tsRNA inhibited translation in a sequence-independent manner [12]. A recent report supported this finding by showing that type I $5^{\prime}$ tsRNA interacts with the human multisynthetase complex (MSC) [124], which is critical for translation elongation. tsRNAs interfere not only in the translation initiation/elongation step, but can also enhance translation efficiency through ribosomal RNA processing [13]. Regarding this regulation mechanism, the LeuCAG3' tsRNA (type I) that is 
upregulated in hepatocellular carcinoma interacts with some ribosomal protein (RPS15 and RPS28) mRNAs to increase their production.

Interestingly, the role of tsRNAs in cancer was initially proposed from a bladder cancer-derived tRNA fragment that inhibited endothelial cell growth [125]. In addition, early reports on tsRNAs suggested that they have a function in cancer [77]. Several studies identified tsRNA signatures in breast cancer [25,78], and pan-cancer studies that followed also detected some signatures [52,78], suggesting that deregulated tsRNA production plays critical roles in cancer. Indeed, an early report on B-cell lymphoma described a tRNA-derived microRNA, namely, CU1276 (type I tsRNA), that represses RPA1 expression, thereby regulating the DNA damage response [63]. Likewise, tRF5-Glu (tRNA halves) was reported to suppress BCAR3 expression by binding to its $3^{\prime}$ UTR, resulting in the inhibition of ovarian cell proliferation [126]. A recent study also showed that type I 3' tRF-3019a plays an oncogenic role in gastric cancer, via the regulation of the tumor suppressor FBXO47 [127]. Most of these regulation processes involve microRNA-like repression, mainly via UTR interaction [91]. Considering the critical role of tsRNAs in translation, further investigation on the role of these molecules in various types of cancer will expand our understanding of the oncogenic or tumor-suppressive functions of tsRNAs.

\section{Conclusions}

The roles of tsRNAs in cancer constitute a rapidly emerging area of study. One of the unique characteristics of tsRNAs is their ability to interact with either Argonaute or PIWI proteins [128]. This implies that the functions of tsRNAs may be more diverse than those discovered so far. As described here, tsRNAs are mainly involved in ribosomal and translation regulation, but their epigenetic modification capacities indicate that they also play important roles in immune cells, germ cells, adipocytes, and cancer cells (summarized in the Table 1).

Table 1. Summarized types and function of tsRNA(s) related to epigenetic regulation.

\begin{tabular}{|c|c|c|c|c|}
\hline Type of tsRNA(s) & Common Name & Example of tsRNA(s) & Function & $\begin{array}{l}\text { Ref. } \\
\text { Number }\end{array}$ \\
\hline & $5^{\prime}$ tsRNA & tRFGluTTC & 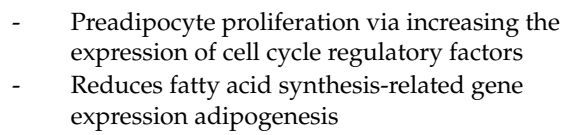 & [112] \\
\hline & & $\begin{array}{l}\text { Twi12-interacting } 3^{\prime} \\
\text { tsRNAs }\end{array}$ & $\begin{array}{l}\text { - } \quad \text { RNA metabolism (stimulated Xrn2 } \\
\text { exonuclease activity) }\end{array}$ & [51] \\
\hline lype 1 & \multirow[t]{3}{*}{$3^{\prime}$ tsRNA } & 18-nt 3' tsRNA & $\begin{array}{l}\text { Interrupts reverse transcription of ERVs by } \\
\text { competing for the primer binding site (PBS) }\end{array}$ & \multirow[t]{2}{*}{ [103] } \\
\hline & & 22-nt 3' tsRNA & $\begin{array}{l}\text { - Induces post-transcriptional silencing of } \\
\text { retroviral proteins by targeting their mRNA }\end{array}$ & \\
\hline & & LeuCAG3' tsRNA & - $\quad$ Translation regulation of ribosomal protein & {$[13]$} \\
\hline \multirow{2}{*}{ Type II } & & ts $-53 \&$ ts -101 & $\begin{array}{ll}\text { - } & \text { Loss derepresses TCL1 expression } \\
\text { - } & \text { Interacts with PiwiL2 }\end{array}$ & {$[52,91]$} \\
\hline & & tRF-1001 & - $\quad$ Regulation of cell cycle & {$[4]$} \\
\hline
\end{tabular}


Table 1. Cont.

\begin{tabular}{|c|c|c|c|c|}
\hline Type of tsRNA(s) & Common Name & Example of tsRNA(s) & Function & $\begin{array}{c}\text { Ref. } \\
\text { Number }\end{array}$ \\
\hline \multirow{3}{*}{ tRNA halves } & \multirow{3}{*}{$5^{\prime}$ tiRNA } & td-piR(Glu) & - Inhibition of CD1A transcription & [90] \\
\hline & & $\begin{array}{l}\text { Sperm } \\
\text { 5' tRNA halve(s) }\end{array}$ & $\begin{array}{l}\text { - } \quad \text { Transmission of metabolic phenotypes } \\
\text { - } \quad \text { Involved in epigenetic inheritance }\end{array}$ & [119-122] \\
\hline & & $\begin{array}{l}\text { Sperm } \\
5^{\prime} \text { tRF-Gly-GCC }\end{array}$ & $\begin{array}{ll}\text { - } & \text { Downregulation of the MERVL retroelement } \\
\text { - } & \text { Affects chromatin accessibility }\end{array}$ & [111] \\
\hline
\end{tabular}

Similar to other small RNAs, antisense oligonucleotide technologies have been used to inhibit tsRNAs in multiple studies [13,81]. Despite the existing limitations in the development of these antisense tsRNA inhibitors, future research will continue this effort to control the expression of specific tsRNAs. Furthermore, investigating key factors in the biogenesis of cancer-related tsRNAs will provide alternative approaches to regulate abnormal tsRNA levels. Especially, through the identification of specific nucleases responsible for tRNA cleavage and the development of specific inhibitors, it will be possible to control the abnormal production of tsRNAs related to human diseases. Considering that cancer development has generally been linked to elevated translation rates and consequently, to high levels of tRNAs, understanding how cancer cells manage tsRNA levels and avoid unexpected side effects is also an important issue to pursue. These studies will collectively help us understand the role of tsRNAs in epigenetic modification and will enable us to develop novel cancer treatments.

Author Contributions: J.P. and S.H.A. performed literature search, wrote draft and drew figures. M.G.S. helped on writing and made Table. H.K.K. and S.C. conceived idea, structured the manuscript and finalized writing. All authors have read and agreed to the published version of the manuscript.

Funding: This research was supported by a grant from the Asan Institute for Life Sciences (2019IP0571-1) and by the Chung-Ang University Research Grants in 2019.

Acknowledgments: We thank to Daesik Kim (KRIBB) for helpful comments.

Conflicts of Interest: The authors declare no conflict of interest.

\section{References}

1. Zhou, L.; Li, X.; Liu, Q.; Zhao, F.; Wu, J. Small RNA transcriptome investigation based on next-generation sequencing technology. J. Genet. Genom. 2011, 38, 505-513. [CrossRef] [PubMed]

2. Cole, C.; Sobala, A.; Lu, C.; Thatcher, S.R.; Bowman, A.; Brown, J.W.; Green, P.J.; Barton, G.J.; Hutvagner, G. Filtering of deep sequencing data reveals the existence of abundant Dicer-dependent small RNAs derived from tRNAs. RNA 2009, 15, 2147-2160. [CrossRef] [PubMed]

3. Li, S.; Xu, Z.; Sheng, J. tRNA-Derived Small RNA: A Novel Regulatory Small Non-Coding RNA. Genes 2018, 9, 246. [CrossRef] [PubMed]

4. Lee, Y.S.; Shibata, Y.; Malhotra, A.; Dutta, A. A novel class of small RNAs: tRNA-derived RNA fragments (tRFs). Genes Dev. 2009, 23, 2639-2649. [CrossRef]

5. Haussecker, D.; Huang, Y.; Lau, A.; Parameswaran, P.; Fire, A.Z.; Kay, M.A. Human tRNA-derived small RNAs in the global regulation of RNA silencing. RNA 2010, 16, 673-695. [CrossRef] [PubMed]

6. Iben, J.R.; Maraia, R.J. tRNA gene copy number variation in humans. Gene 2014, 536, 376-384. [CrossRef]

7. Schimmel, P. The emerging complexity of the tRNA world: Mammalian tRNAs beyond protein synthesis. Nat. Rev. Mol. Cell Biol. 2018, 19, 45-58. [CrossRef]

8. Selitsky, S.R.; Sethupathy, P. tDRmapper: Challenges and solutions to mapping, naming, and quantifying tRNA-derived RNAs from human small RNA-sequencing data. BMC Bioinform. 2015, 16, 354. [CrossRef]

9. Shi, J.; Ko, E.A.; Sanders, K.M.; Chen, Q.; Zhou, T. SPORTS1.0: A Tool for Annotating and Profiling Non-coding RNAs Optimized for rRNA- and tRNA-derived Small RNAs. Genom. Proteom. Bioinform. 2018, 16, 144-151. [CrossRef] 
10. La Ferlita, A.; Alaimo, S.; Veneziano, D.; Nigita, G.; Balatti, V.; Croce, C.M.; Ferro, A.; Pulvirenti, A. Identification of tRNA-derived ncRNAs in TCGA and NCI-60 panel cell lines and development of the public database tRFexplorer. Database 2019, 2019. [CrossRef]

11. Pederson, T. Regulatory RNAs derived from transfer RNA? RNA 2010, 16, 1865-1869. [CrossRef] [PubMed]

12. Sobala, A.; Hutvagner, G. Small RNAs derived from the $5^{\prime}$ end of tRNA can inhibit protein translation in human cells. RNA Biol. 2013, 10, 553-563. [CrossRef] [PubMed]

13. Kim, H.K.; Fuchs, G.; Wang, S.; Wei, W.; Zhang, Y.; Park, H.; Roy-Chaudhuri, B.; Li, P.; Xu, J.; Chu, K.; et al. A transfer-RNA-derived small RNA regulates ribosome biogenesis. Nature 2017, 552, 57-62. [CrossRef] [PubMed]

14. Gebetsberger, J.; Wyss, L.; Mleczko, A.M.; Reuther, J.; Polacek, N. A tRNA-derived fragment competes with mRNA for ribosome binding and regulates translation during stress. RNA Biol. 2017, 14, 1364-1373. [CrossRef] [PubMed]

15. Kim, H.K.; Xu, J.; Chu, K.; Park, H.; Jang, H.; Li, P.; Valdmanis, P.N.; Zhang, Q.C.; Kay, M.A. A tRNA-Derived Small RNA Regulates Ribosomal Protein S28 Protein Levels after Translation Initiation in Humans and Mice. Cell Rep. 2019, 29, 3816-3824.e3814. [CrossRef] [PubMed]

16. Goodarzi, H.; Liu, X.; Nguyen, H.C.; Zhang, S.; Fish, L.; Tavazoie, S.F. Endogenous tRNA-Derived Fragments Suppress Breast Cancer Progression via YBX1 Displacement. Cell 2015, 161, 790-802. [CrossRef]

17. Oberbauer, V.; Schaefer, M.R. tRNA-Derived Small RNAs: Biogenesis, Modification, Function and Potential Impact on Human Disease Development. Genes 2018, 9, 607. [CrossRef]

18. Garcia-Silva, M.R.; Cabrera-Cabrera, F.; Guida, M.C.; Cayota, A. Hints of tRNA-Derived Small RNAs Role in RNA Silencing Mechanisms. Genes 2012, 3, 603-614. [CrossRef]

19. Ruggero, K.; Guffanti, A.; Corradin, A.; Sharma, V.K.; De Bellis, G.; Corti, G.; Grassi, A.; Zanovello, P.; Bronte, V.; Ciminale, V.; et al. Small noncoding RNAs in cells transformed by human T-cell leukemia virus type 1: A role for a tRNA fragment as a primer for reverse transcriptase. J. Virol. 2014, 88, 3612-3622. [CrossRef]

20. Kuscu, C.; Kumar, P.; Kiran, M.; Su, Z.; Malik, A.; Dutta, A. tRNA fragments (tRFs) guide Ago to regulate gene expression post-transcriptionally in a Dicer-independent manner. RNA 2018, 24, 1093-1105. [CrossRef]

21. Zhou, J.; Wan, F.; Wang, Y.; Long, J.; Zhu, X. Small RNA sequencing reveals a novel tsRNA-26576 mediating tumorigenesis of breast cancer. Cancer Manag. Res. 2019, 11, 3945-3956. [CrossRef] [PubMed]

22. Zhang, M.; Li, F.; Wang, J.; He, W.; Li, Y.; Li, H.; Wei, Z.; Cao, Y. tRNA-derived fragment tRF-03357 promotes cell proliferation, migration and invasion in high-grade serous ovarian cancer. Onco. Targets 2019, 12, 6371-6383. [CrossRef] [PubMed]

23. Liu, S.; Chen, Y.; Ren, Y.; Zhou, J.; Ren, J.; Lee, I.; Bao, X. A tRNA-derived RNA Fragment Plays an Important Role in the Mechanism of Arsenite -induced Cellular Responses. Sci. Rep. 2018, 8, 16838. [CrossRef] [PubMed]

24. Zhu, L.; Li, J.; Gong, Y.; Wu, Q.; Tan, S.; Sun, D.; Xu, X.; Zuo, Y.; Zhao, Y.; Wei, Y.Q.; et al. Exosomal tRNA-derived small RNA as a promising biomarker for cancer diagnosis. Mol. Cancer 2019, 18, 74. [CrossRef]

25. Dhahbi, J.M.; Spindler, S.R.; Atamna, H.; Boffelli, D.; Martin, D.I. Deep Sequencing of Serum Small RNAs Identifies Patterns of 5' tRNA Half and YRNA Fragment Expression Associated with Breast Cancer. Biomark. Cancer 2014, 6, 37-47. [CrossRef]

26. Shen, Y.; Yu, X.; Zhu, L.; Li, T.; Yan, Z.; Guo, J. Transfer RNA-derived fragments and tRNA halves: Biogenesis, biological functions and their roles in diseases. J. Mol. Med. 2018, 96, 1167-1176. [CrossRef]

27. Godoy, P.M.; Bhakta, N.R.; Barczak, A.J.; Cakmak, H.; Fisher, S.; MacKenzie, T.C.; Patel, T.; Price, R.W.; Smith, J.F.; Woodruff, P.G.; et al. Large Differences in Small RNA Composition Between Human Biofluids. Cell Rep. 2018, 25, 1346-1358. [CrossRef]

28. Zhang, Y.; Zhang, Y.; Shi, J.; Zhang, H.; Cao, Z.; Gao, X.; Ren, W.; Ning, Y.; Ning, L.; Cao, Y.; et al. Identification and characterization of an ancient class of small RNAs enriched in serum associating with active infection. J. Mol. Cell Biol. 2014, 6, 172-174. [CrossRef]

29. Dhahbi, J.M.; Atamna, H.; Selth, L.A. Data Mining of Small RNA-Seq Suggests an Association Between Prostate Cancer and Altered Abundance of 5' Transfer RNA Halves in Seminal Fluid and Prostatic Tissues. Biomark. Cancer 2018, 10. [CrossRef]

30. Guo, Y.; Strickland, S.A.; Mohan, S.; Li, S.; Bosompem, A.; Vickers, K.C.; Zhao, S.; Sheng, Q.; Kim, A.S. MicroRNAs and tRNA-derived fragments predict the transformation of myelodysplastic syndromes to acute myeloid leukemia. Leuk. Lymphoma 2017, 58, 1-15. [CrossRef] 
31. Guzzi, N.; Ciesla, M.; Ngoc, P.C.T.; Lang, S.; Arora, S.; Dimitriou, M.; Pimkova, K.; Sommarin, M.N.E.; Munita, R.; Lubas, M.; et al. Pseudouridylation of tRNA-Derived Fragments Steers Translational Control in Stem Cells. Cell 2018, 173, 1204-1216.e1226. [CrossRef] [PubMed]

32. Kikuchi, Y.; Sasaki, N.; Ando-Yamagami, Y. Cleavage of tRNA within the mature tRNA sequence by the catalytic RNA of RNase P: Implication for the formation of the primer tRNA fragment for reverse transcription in copia retrovirus-like particles. Proc. Natl. Acad. Sci. USA 1990, 87, 8105-8109. [CrossRef]

33. Kikuchi, Y. RNase P as hyperprocessing enzyme: A model for formation of a biologically functional tRNA fragment. Mol. Biol Rep. 1995, 22, 171-175. [CrossRef]

34. Martinez, G.; Choudury, S.G.; Slotkin, R.K. tRNA-derived small RNAs target transposable element transcripts. Nucleic Acids Res. 2017, 45, 5142-5152. [CrossRef] [PubMed]

35. Boskovic, A.; Bing, X.Y.; Kaymak, E.; Rando, O.J. Control of noncoding RNA production and histone levels by a $5^{\prime}$ tRNA fragment. Genes Dev. 2020, 34, 118-131. [CrossRef] [PubMed]

36. Mo, D.; Jiang, P.; Yang, Y.; Mao, X.; Tan, X.; Tang, X.; Wei, D.; Li, B.; Wang, X.; Tang, L.; et al. A tRNA fragment, $5^{\prime}$-tiRNA(Val), suppresses the Wnt/beta-catenin signaling pathway by targeting FZD3 in breast cancer. Cancer Lett. 2019, 457, 60-73. [CrossRef]

37. Balatti, V.; Nigita, G.; Veneziano, D.; Drusco, A.; Stein, G.S.; Messier, T.L.; Farina, N.H.; Lian, J.B.; Tomasello, L.; Liu, C.G.; et al. tsRNA signatures in cancer. Proc. Natl. Acad. Sci. USA 2017, 114, 8071-8076. [CrossRef]

38. Su, Z.; Kuscu, C.; Malik, A.; Shibata, E.; Dutta, A. Angiogenin generates specific stress-induced tRNA halves and is not involved in tRF-3-mediated gene silencing. J. Biol. Chem. 2019, 294, 16930-16941. [CrossRef]

39. Zheng, L.L.; Xu, W.L.; Liu, S.; Sun, W.J.; Li, J.H.; Wu, J.; Yang, J.H.; Qu, L.H. tRF2Cancer: A web server to detect tRNA-derived small RNA fragments (tRFs) and their expression in multiple cancers. Nucleic Acids Res. 2016, 44, W185-W193. [CrossRef]

40. Baylin, S.B.; Jones, P.A. Epigenetic determinants of cancer. Cold Spring Harb. Perspect. Biol. 2016, 8, a019505. [CrossRef]

41. Garraway, L.A.; Lander, E.S. Lessons from the cancer genome. Cell 2013, 153, 17-37. [CrossRef] [PubMed]

42. Audia, J.E.; Campbell, R.M. Histone modifications and cancer. Cold Spring Harb. Perspect. Biol. 2016, 8, a019521. [CrossRef] [PubMed]

43. Shen, H.; Laird, P.W. Interplay between the cancer genome and epigenome. Cell 2013, 153, 38-55. [CrossRef] [PubMed]

44. Jones, P.A.; Baylin, S.B. The fundamental role of epigenetic events in cancer. Nat. Rev. Genet. 2002, 3, 415-428. [CrossRef]

45. Laird, P.W.; Jackson-Grusby, L.; Fazeli, A.; Dickinson, S.L.; Jung, W.E.; Li, E.; Weinberg, R.A.; Jaenisch, R. Suppression of intestinal neoplasia by DNA hypomethylation. Cell 1995, 81, 197-205. [CrossRef]

46. Sansom, O.J.; Berger, J.; Bishop, S.M.; Hendrich, B.; Bird, A.; Clarke, A.R. Deficiency of Mbd2 suppresses intestinal tumorigenesis. Nat. Genet. 2003, 34, 145-147. [CrossRef]

47. Prokhortchouk, A.; Sansom, O.; Selfridge, J.; Caballero, I.M.; Salozhin, S.; Aithozhina, D.; Cerchietti, L.; Meng, F.G.; Augenlicht, L.H.; Mariadason, J.M. Kaiso-deficient mice show resistance to intestinal cancer. Mol. Cell. Biol. 2006, 26, 199-208. [CrossRef] [PubMed]

48. De Carvalho, D.D.; Sharma, S.; You, J.S.; Su, S.-F.; Taberlay, P.C.; Kelly, T.K.; Yang, X.; Liang, G.; Jones, P.A. DNA methylation screening identifies driver epigenetic events of cancer cell survival. Cancer Cell 2012, 21, 655-667. [CrossRef]

49. Le Thomas, A.; Stuwe, E.; Li, S.; Du, J.; Marinov, G.; Rozhkov, N.; Chen, Y.C.; Luo, Y.; Sachidanandam, R.; Toth, K.F.; et al. Transgenerationally inherited piRNAs trigger piRNA biogenesis by changing the chromatin of piRNA clusters and inducing precursor processing. Genes Dev. 2014, 28, 1667-1680. [CrossRef]

50. Watanabe, T.; Cui, X.; Yuan, Z.; Qi, H.; Lin, H. MIWI2 targets RNAs transcribed from piRNA-dependent regions to drive DNA methylation in mouse prospermatogonia. EMBO J. 2018, 37. [CrossRef]

51. Couvillion, M.T.; Sachidanandam, R.; Collins, K. A growth-essential Tetrahymena Piwi protein carries tRNA fragment cargo. Genes Dev. 2010, 24, 2742-2747. [CrossRef] [PubMed]

52. Pekarsky, Y.; Balatti, V.; Palamarchuk, A.; Rizzotto, L.; Veneziano, D.; Nigita, G.; Rassenti, L.Z.; Pass, H.I.; Kipps, T.J.; Liu, C.G.; et al. Dysregulation of a family of short noncoding RNAs, tsRNAs, in human cancer. Proc. Natl. Acad. Sci. USA 2016, 113, 5071-5076. [CrossRef] [PubMed]

53. Hopper, A.K.; Nostramo, R.T. tRNA Processing and Subcellular Trafficking Proteins Multitask in Pathways for Other RNAs. Front. Genet. 2019, 10. [CrossRef] [PubMed] 
54. Pan, T. Modifications and functional genomics of human transfer RNA. Cell Res. 2018, 28, 395-404. [CrossRef] [PubMed]

55. Abbott, J.A.; Francklyn, C.S.; Robey-Bond, S.M. Transfer RNA and human disease. Front. Genet. 2014, 5, 158. [CrossRef]

56. Huang, S.Q.; Sun, B.; Xiong, Z.P.; Shu, Y.; Zhou, H.H.; Zhang, W.; Xiong, J.; Li, Q. The dysregulation of tRNAs and tRNA derivatives in cancer. J. Exp. Clin. Cancer Res. 2018, 37, 101. [CrossRef]

57. Ivanov, P.; O’Day, E.; Emara, M.M.; Wagner, G.; Lieberman, J.; Anderson, P. G-quadruplex structures contribute to the neuroprotective effects of angiogenin-induced tRNA fragments. Proc. Natl. Acad. Sci. USA 2014, 111, 18201-18206. [CrossRef]

58. Gupta, R.A.; Shah, N.; Wang, K.C.; Kim, J.; Horlings, H.M.; Wong, D.J.; Tsai, M.C.; Hung, T.; Argani, P.; Rinn, J.L.; et al. Long non-coding RNA HOTAIR reprograms chromatin state to promote cancer metastasis. Nature 2010, 464, 1071-1076. [CrossRef]

59. Goodarzi, H.; Nguyen, H.C.B.; Zhang, S.; Dill, B.D.; Molina, H.; Tavazoie, S.F. Modulated Expression of Specific tRNAs Drives Gene Expression and Cancer Progression. Cell 2016, 165, 1416-1427. [CrossRef]

60. Farina, N.H.; Scalia, S.; Adams, C.E.; Hong, D.; Fritz, A.J.; Messier, T.L.; Balatti, V.; Veneziano, D.; Lian, J.B.; Croce, C.M.; et al. Identification of tRNA-derived small RNA (tsRNA) responsive to the tumor suppressor, RUNX1, in breast cancer. J. Cell. Physiol. 2020, 235, 5318-5327. [CrossRef]

61. Yamasaki, S.; Ivanov, P.; Hu, G.F.; Anderson, P. Angiogenin cleaves tRNA and promotes stress-induced translational repression. J. Cell Biol. 2009, 185, 35-42. [CrossRef]

62. Gebetsberger, J.; Zywicki, M.; Künzi, A.; Polacek, N. tRNA-derived fragments target the ribosome and function as regulatory non-coding RNA in Haloferax volcanii. Archaea 2012, 2012, 260909. [CrossRef] [PubMed]

63. Kumar, P.; Anaya, J.; Mudunuri, S.B.; Dutta, A. Meta-analysis of tRNA derived RNA fragments reveals that they are evolutionarily conserved and associate with AGO proteins to recognize specific RNA targets. BMC Biol. 2014, 12, 78. [CrossRef] [PubMed]

64. Babiarz, J.E.; Ruby, J.G.; Wang, Y.; Bartel, D.P.; Blelloch, R. Mouse ES cells express endogenous shRNAs, siRNAs, and other Microprocessor-independent, Dicer-dependent small RNAs. Genes Dev. 2008, 22, 2773-2785. [CrossRef] [PubMed]

65. Yeung, M.L.; Bennasser, Y.; Watashi, K.; Le, S.Y.; Houzet, L.; Jeang, K.T. Pyrosequencing of small non-coding RNAs in HIV-1 infected cells: Evidence for the processing of a viral-cellular double-stranded RNA hybrid. Nucleic Acids Res. 2009, 37, 6575-6586. [CrossRef] [PubMed]

66. Maute, R.L.; Schneider, C.; Sumazin, P.; Holmes, A.; Califano, A.; Basso, K.; Dalla-Favera, R. tRNA-derived microRNA modulates proliferation and the DNA damage response and is down-regulated in B cell lymphoma. Proc. Natl. Acad. Sci. USA 2013, 110, 1404-1409. [CrossRef]

67. Li, Z.; Ender, C.; Meister, G.; Moore, P.S.; Chang, Y.; John, B. Extensive terminal and asymmetric processing of small RNAs from rRNAs, snoRNAs, snRNAs, and tRNAs. Nucleic Acids Res. 2012, 40, 6787-6799. [CrossRef] [PubMed]

68. Schramm, L.; Hernandez, N. Recruitment of RNA polymerase III to its target promoters. Genes Dev. 2002, 16, 2593-2620. [CrossRef]

69. Takaku, H.; Minagawa, A.; Takagi, M.; Nashimoto, M. A candidate prostate cancer susceptibility gene encodes tRNA 3' processing endoribonuclease. Nucleic Acids Res. 2003, 31, 2272-2278. [CrossRef]

70. Lee, S.R.; Collins, K. Starvation-induced cleavage of the tRNA anticodon loop in Tetrahymena thermophila. J. Biol. Chem. 2005, 280, 42744-42749. [CrossRef]

71. Honda, S.; Loher, P.; Shigematsu, M.; Palazzo, J.P.; Suzuki, R.; Imoto, I.; Rigoutsos, I.; Kirino, Y. Sex hormone-dependent tRNA halves enhance cell proliferation in breast and prostate cancers. Proc. Natl. Acad. Sci. USA 2015, 112, E3816-E3825. [CrossRef]

72. Levitz, R.; Chapman, D.; Amitsur, M.; Green, R.; Snyder, L.; Kaufmann, G. The optional E. coli prr locus encodes a latent form of phage T4-induced anticodon nuclease. EMBO J. 1990, 9, 1383-1389. [CrossRef] [PubMed]

73. Haiser, H.J.; Karginov, F.V.; Hannon, G.J.; Elliot, M.A. Developmentally regulated cleavage of tRNAs in the bacterium Streptomyces coelicolor. Nucleic Acids Res. 2008, 36, 732-741. [CrossRef] [PubMed]

74. Jöchl, C.; Rederstorff, M.; Hertel, J.; Stadler, P.F.; Hofacker, I.L.; Schrettl, M.; Haas, H.; Hüttenhofer, A. Small ncRNA transcriptome analysis from Aspergillus fumigatus suggests a novel mechanism for regulation of protein synthesis. Nucleic Acids Res. 2008, 36, 2677-2689. [CrossRef] [PubMed] 
75. Thompson, D.M.; Lu, C.; Green, P.J.; Parker, R. tRNA cleavage is a conserved response to oxidative stress in eukaryotes. RNA 2008, 14, 2095-2103. [CrossRef] [PubMed]

76. Fu, H.; Feng, J.; Liu, Q.; Sun, F.; Tie, Y.; Zhu, J.; Xing, R.; Sun, Z.; Zheng, X. Stress induces tRNA cleavage by angiogenin in mammalian cells. FEBS Lett. 2009, 583, 437-442. [CrossRef] [PubMed]

77. Shapiro, R.; Vallee, B.L. Human placental ribonuclease inhibitor abolishes both angiogenic and ribonucleolytic activities of angiogenin. Proc. Natl. Acad. Sci. USA 1987, 84, 2238-2241. [CrossRef]

78. Lee, F.S.; Shapiro, R.; Vallee, B.L. Tight-binding inhibition of angiogenin and ribonuclease A by placental ribonuclease inhibitor. Biochemistry 1989, 28, 225-230. [CrossRef]

79. Tsuji, T.; Sun, Y.; Kishimoto, K.; Olson, K.A.; Liu, S.; Hirukawa, S.; Hu, G.F. Angiogenin is translocated to the nucleus of HeLa cells and is involved in ribosomal RNA transcription and cell proliferation. Cancer Res. 2005, 65, 1352-1360. [CrossRef]

80. Thompson, D.M.; Parker, R. Stressing out over tRNA cleavage. Cell 2009, 138, 215-219. [CrossRef]

81. Telonis, A.G.; Loher, P.; Honda, S.; Jing, Y.; Palazzo, J.; Kirino, Y.; Rigoutsos, I. Dissecting tRNA-derived fragment complexities using personalized transcriptomes reveals novel fragment classes and unexpected dependencies. Oncotarget 2015, 6, 24797-24822. [CrossRef] [PubMed]

82. Kumar, P.; Kuscu, C.; Dutta, A. Biogenesis and Function of Transfer RNA-Related Fragments (tRFs). Trends Biochem. Sci. 2016, 41, 679-689. [CrossRef] [PubMed]

83. Hanada, T.; Weitzer, S.; Mair, B.; Bernreuther, C.; Wainger, B.J.; Ichida, J.; Hanada, R.; Orthofer, M.; Cronin, S.J.; Komnenovic, V.; et al. CLP1 links tRNA metabolism to progressive motor-neuron loss. Nature 2013, 495, 474-480. [CrossRef] [PubMed]

84. Kumar, P.; Mudunuri, S.B.; Anaya, J.; Dutta, A. tRFdb: A database for transfer RNA fragments. Nucleic Acids Res. 2015, 43, D141-D145. [CrossRef] [PubMed]

85. Thomson, T.; Lin, H. The biogenesis and function of PIWI proteins and piRNAs: Progress and prospect. Annu. Rev. Cell Dev. Biol. 2009, 25, 355-376. [CrossRef] [PubMed]

86. Lin, H.; Spradling, A.C. A novel group of pumilio mutations affects the asymmetric division of germline stem cells in the Drosophila ovary. Development 1997, 124, 2463-2476.

87. Carmell, M.A.; Girard, A.; van de Kant, H.J.; Bourc'his, D.; Bestor, T.H.; de Rooij, D.G.; Hannon, G.J. MIWI2 is essential for spermatogenesis and repression of transposons in the mouse male germline. Dev. Cell 2007, 12, 503-514. [CrossRef]

88. Das, P.P.; Bagijn, M.P.; Goldstein, L.D.; Woolford, J.R.; Lehrbach, N.J.; Sapetschnig, A.; Buhecha, H.R.; Gilchrist, M.J.; Howe, K.L.; Stark, R.; et al. Piwi and piRNAs act upstream of an endogenous siRNA pathway to suppress Tc3 transposon mobility in the Caenorhabditis elegans germline. Mol. Cell 2008, 31, 79-90. [CrossRef]

89. Houwing, S.; Kamminga, L.M.; Berezikov, E.; Cronembold, D.; Girard, A.; van den Elst, H.; Filippov, D.V.; Blaser, H.; Raz, E.; Moens, C.B.; et al. A role for Piwi and piRNAs in germ cell maintenance and transposon silencing in Zebrafish. Cell 2007, 129, 69-82. [CrossRef]

90. Siomi, M.C.; Sato, K.; Pezic, D.; Aravin, A.A. PIWI-interacting small RNAs: The vanguard of genome defence. Nat. Rev. Mol. Cell Biol. 2011, 12, 246-258. [CrossRef]

91. Couvillion, M.T.; Lee, S.R.; Hogstad, B.; Malone, C.D.; Tonkin, L.A.; Sachidanandam, R.; Hannon, G.J.; Collins, K. Sequence, biogenesis, and function of diverse small RNA classes bound to the Piwi family proteins of Tetrahymena thermophila. Genes Dev. 2009, 23, 2016-2032. [CrossRef] [PubMed]

92. Couvillion, M.T.; Bounova, G.; Purdom, E.; Speed, T.P.; Collins, K. A Tetrahymena Piwi bound to mature tRNA $3^{\prime}$ fragments activates the exonuclease Xrn2 for RNA processing in the nucleus. Mol. Cell 2012, 48, 509-520. [CrossRef] [PubMed]

93. Zhang, X.; He, X.; Liu, C.; Liu, J.; Hu, Q.; Pan, T.; Duan, X.; Liu, B.; Zhang, Y.; Chen, J.; et al. IL-4 Inhibits the Biogenesis of an Epigenetically Suppressive PIWI-Interacting RNA To Upregulate CD1a Molecules on Monocytes/Dendritic Cells. J. Immunol. 2016, 196, 1591-1603. [CrossRef] [PubMed]

94. Balatti, V.; Rizzotto, L.; Miller, C.; Palamarchuk, A.; Fadda, P.; Pandolfo, R.; Rassenti, L.Z.; Hertlein, E.; Ruppert, A.S.; Lozanski, A.; et al. TCL1 targeting miR-3676 is codeleted with tumor protein p53 in chronic lymphocytic leukemia. Proc. Natl. Acad. Sci. USA 2015, 112, 2169-2174. [CrossRef]

95. Chénais, B. Transposable elements in cancer and other human diseases. Curr. Cancer Drug Targets 2015, 15, 227-242. [CrossRef] 
96. International Human Genome Sequencing Consortium. Initial sequencing and analysis of the human genome. Nature 2001, 409, 860-921. [CrossRef]

97. Slotkin, R.K.; Martienssen, R. Transposable elements and the epigenetic regulation of the genome. Nat. Rev. Genet. 2007, 8, 272-285. [CrossRef]

98. Chénais, B. Transposable elements and human cancer: A causal relationship? Biochim. Biophys. Acta BBA Rev. Cancer 2013, 1835, 28-35. [CrossRef]

99. Chénais, B.; Caruso, A.; Hiard, S.; Casse, N. The impact of transposable elements on eukaryotic genomes: From genome size increase to genetic adaptation to stressful environments. Gene 2012, 509, 7-15. [CrossRef]

100. Anwar, S.L.; Wulaningsih, W.; Lehmann, U. Transposable Elements in Human Cancer: Causes and Consequences of Deregulation. Int. J. Mol. Sci. 2017, 18, 974. [CrossRef]

101. Saleh, A.; Macia Ortega, A.; Muotri, A.R. Transposable Elements, Inflammation and Neurological Disease. Front. Neurol. 2019, 10, 894. [CrossRef] [PubMed]

102. Zhang, Y.; Shi, J.; Chen, Q. tsRNAs: New players in mammalian retrotransposon control. Cell Res. 2017, 27, 1307-1308. [CrossRef]

103. Watanabe, T.; Tomizawa, S.-I.; Mitsuya, K.; Totoki, Y.; Yamamoto, Y.; Kuramochi-Miyagawa, S.; Iida, N.; Hoki, Y.; Murphy, P.J.; Toyoda, A. Role for piRNAs and noncoding RNA in de novo DNA methylation of the imprinted mouse Rasgrf1 locus. Science 2011, 332, 848-852. [CrossRef] [PubMed]

104. Hadjiargyrou, M.; Delihas, N. The intertwining of transposable elements and non-coding RNAs. Int. J. Mol. Sci. 2013, 14, 13307-13328. [CrossRef] [PubMed]

105. Chen, Q.; Yan, W.; Duan, E. Epigenetic inheritance of acquired traits through sperm RNAs and sperm RNA modifications. Nat. Rev. Genet. 2016, 17, 733. [CrossRef]

106. Andrea, J.; Michael, J. LTR-Retrotransposon Control by tRNA-Derived Small RNAs. Cell 2017, 170, 61-71.

107. Karimi, M.M.; Goyal, P.; Maksakova, I.A.; Bilenky, M.; Leung, D.; Tang, J.X.; Shinkai, Y.; Mager, D.L.; Jones, S.; Hirst, M. DNA methylation and SETDB1/H3K9me3 regulate predominantly distinct sets of genes, retroelements, and chimeric transcripts in mESCs. Cell Stem Cell 2011, 8, 676-687. [CrossRef]

108. Matsui, T.; Leung, D.; Miyashita, H.; Maksakova, I.A.; Miyachi, H.; Kimura, H.; Tachibana, M.; Lorincz, M.C.; Shinkai, Y. Proviral silencing in embryonic stem cells requires the histone methyltransferase ESET. Nature 2010, 464, 927-931. [CrossRef]

109. Klemm, S.L.; Shipony, Z.; Greenleaf, W.J. Chromatin accessibility and the regulatory epigenome. Nat. Rev. Genet. 2019, 20, 207-220. [CrossRef]

110. Barucci, G.; Cornes, E.; Singh, M.; Li, B.; Ugolini, M.; Samolygo, A.; Didier, C.; Dingli, F.; Loew, D.; Quarato, P.; et al. Small-RNA-mediated transgenerational silencing of histone genes impairs fertility in piRNA mutants. Nat. Cell Biol. 2020, 22, 235-245. [CrossRef]

111. Fields, B.D.; Kennedy, S. Chromatin Compaction by Small RNAs and the Nuclear RNAi Machinery in C. elegans. Sci. Rep. 2019, 9, 9030. [CrossRef] [PubMed]

112. Komarov, P.A.; Sokolova, O.; Akulenko, N.; Brasset, E.; Jensen, S.; Kalmykova, A. Epigenetic Requirements for Triggering Heterochromatinization and Piwi-Interacting RNA Production from Transgenes in the Drosophila Germline. Cells 2020, 9, 922. [CrossRef] [PubMed]

113. Shen, L.; Tan, Z.; Gan, M.; Li, Q.; Chen, L.; Niu, L.; Jiang, D.; Zhao, Y.; Wang, J.; Li, X.; et al. tRNA-Derived Small Non-Coding RNAs as Novel Epigenetic Molecules Regulating Adipogenesis. Biomolecules 2019, 9, 274. [CrossRef] [PubMed]

114. Resnitzky, D.; Gossen, M.; Bujard, H.; Reed, S. Acceleration of the G1/S phase transition by expression of cyclins D1 and E with an inducible system. Mol. Cell. Biol. 1994, 14, 1669-1679. [CrossRef] [PubMed]

115. Li, W.; Kotoshiba, S.; Berthet, C.; Hilton, M.B.; Kaldis, P. Rb/Cdk2/Cdk4 triple mutant mice elicit an alternative mechanism for regulation of the G1/S transition. Proc. Natl. Acad. Sci. USA 2009, 106, 486-491. [CrossRef]

116. Martienssen, R.; Moazed, D. RNAi and heterochromatin assembly. Cold Spring Harb. Perspect. Biol. 2015, 7, a019323. [CrossRef]

117. Sharma, U.; Conine, C.C.; Shea, J.M.; Boskovic, A.; Derr, A.G.; Bing, X.Y.; Belleannee, C.; Kucukural, A.; Serra, R.W.; Sun, F.; et al. Biogenesis and function of tRNA fragments during sperm maturation and fertilization in mammals. Science 2016, 351, 391-396. [CrossRef]

118. Jiang, S.; Wei, H.; Song, T.; Yang, Y.; Zhang, F.; Zhou, Y.; Peng, J.; Jiang, S. KLF13 promotes porcine adipocyte differentiation through PPARgamma activation. Cell Biosci. 2015, 5, 28. [CrossRef] 
119. Lee, H.; Kim, H.J.; Lee, Y.J.; Lee, M.Y.; Choi, H.; Lee, H.; Kim, J.W. Kruppel-like factor KLF8 plays a critical role in adipocyte differentiation. PLOS ONE 2012, 7, e52474. [CrossRef]

120. Pei, H.; Yao, Y.; Yang, Y.; Liao, K.; Wu, J.R. Kruppel-like factor KLF9 regulates PPARgamma transactivation at the middle stage of adipogenesis. Cell Death Differ. 2011, 18, 315-327. [CrossRef]

121. Perez, M.F.; Lehner, B. Intergenerational and transgenerational epigenetic inheritance in animals. Nat. Cell Biol. 2019, 21, 143-151. [CrossRef] [PubMed]

122. Chen, Q.; Yan, M.; Cao, Z.; Li, X.; Zhang, Y.; Shi, J.; Feng, G.H.; Peng, H.; Zhang, X.; Zhang, Y.; et al. Sperm tsRNAs contribute to intergenerational inheritance of an acquired metabolic disorder. Science 2016, 351, 397-400. [CrossRef] [PubMed]

123. Zhang, X.; Chen, Q. A Twist between ROS and Sperm-Mediated Intergenerational Epigenetic Inheritance. Mol. Cell 2020, 78, 371-373. [CrossRef] [PubMed]

124. Sharma, U.; Sun, F.; Conine, C.C.; Reichholf, B.; Kukreja, S.; Herzog, V.A.; Ameres, S.L.; Rando, O.J. Small RNAs Are Trafficked from the Epididymis to Developing Mammalian Sperm. Dev. Cell 2018, 46, 481-494 e486. [CrossRef] [PubMed]

125. Zhang, Y.; Zhang, X.; Shi, J.; Tuorto, F.; Li, X.; Liu, Y.; Liebers, R.; Zhang, L.; Qu, Y.; Qian, J.; et al. Dnmt2 mediates intergenerational transmission of paternally acquired metabolic disorders through sperm small non-coding RNAs. Nat. Cell Biol. 2018, 20, 535-540. [CrossRef] [PubMed]

126. Ivanov, P.; Emara, M.M.; Villen, J.; Gygi, S.P.; Anderson, P. Angiogenin-induced tRNA fragments inhibit translation initiation. Mol. Cell 2011, 43, 613-623. [CrossRef]

127. Keam, S.P.; Sobala, A.; Ten Have, S.; Hutvagner, G. tRNA-Derived RNA Fragments Associate with Human Multisynthetase Complex (MSC) and Modulate Ribosomal Protein Translation. J. Proteome Res. 2017, 16, 413-420. [CrossRef]

128. Zhao, H.; Bojanowski, K.; Ingber, D.E.; Panigrahy, D.; Pepper, M.S.; Montesano, R.; Shing, Y. New role for tRNA and its fragment purified from human urinary bladder carcinoma conditioned medium: Inhibition of endothelial cell growth. J. Cell Biochem. 1999, 76, 109-117. [CrossRef]

(C) 2020 by the authors. Licensee MDPI, Basel, Switzerland. This article is an open access article distributed under the terms and conditions of the Creative Commons Attribution (CC BY) license (http://creativecommons.org/licenses/by/4.0/). 